DOI: https://doi.org/10.14232/actahisp.2020.25.137-152

\title{
VIOLENCE AND PASSION AT COURT: BRUNHILDA, A VISIGOTHIC PRINCESS
}

\author{
EMŐKE HORVÁTH
}

\author{
Károli Gáspár University of the Reformed Church in Hungary
}

\begin{abstract}
Resumen: El ensayo se centra en la figura de una famosa princesa visigoda y analiza por qué el retrato de Brunegilda esbozado por los escritores del siglo VI refleja una imagen de la reina mucho más favorable que las obras de autores posteriores. El autor del ensayo está buscando la respuesta para la pregunta de qué pudo haber llevado a un cambio tan grande en el juicio de la reina, si sus propias acciones proporcionaron una base para cambiar el juicio de los autores, o si otros motivos contribuyeron a oscurecer la imagen.
\end{abstract}

Palabras clave: Brunegilda, reino visigodo, reinos merovingios, Sigebert.

Abstract: The study focuses on the figure of a famous Visigothic Princess and analyzes why the Brunhilda image of the $6^{\text {th }}$ cuentury's authors reflects a much more favorable portrait of the queen than the works of subsequent authors. The author is looking for the answer to what might have led to such a great change in the Queen's judgment, did her own actions provide a basis for changing the authors 'judgment, or did other motives contribute to painting the picture darker?

Keywords: Brunhilda, Visigothic Kingdom, Merovingian Kingdoms, Sigebert.

\section{Introduction}

Most certainly, we have to identify the most cited female Visigothic figure in history as Brunhilda, who became famous and gained notoriety among the outstanding personalities of early medieval women as a Merovingian queen. Her father was Athanagild, a Visigothic ruler, who gave his daughter's hand in marriage to Merovingian King Sigebert I (561-575). Gregory of Tours writes about Brunhilda in the following way:

She was a maiden beautiful in her person, lovely to look at, virtuous and well-behaved, with good sense and a pleasant address. [...] And though she was a follower of the Arian law she was converted by the preaching of the bishops and the admonition of the king himself, and she confessed the blessed Trinity in unity, and believed and was baptized. And she still remains catholic in Christ's name (Gregorius Turonensis, 1951: IV 27) ${ }^{1}$.

${ }^{1}$ The work in English: Gregory of Tours, History of the Franks, trans. Ernest Brehaut, Records of Civilization 2, New York, Columbia University Press 1916. This paper is the English version of 
This description evokes an image of a smart, gentle, both internally and externally beautiful woman who, in compliance with her husband's words, gave up her earlier faith and showed obedient inclination toward converting from Arianism to Orthodoxy. Gregory had linked her figure with purely positive attributes befitting a queen, so the question may arise: how does such a woman become the embodiment of the devil? Had her person truly become as repulsive as sources suggest, and do we see a completely different Brunhilda at the side of her grandson, Theuderich, years later? Jonas, a monk of Bobbio in the 640s, went further than anyone else when he mentions her as a second Jezebel in his hagiographic work entitled Vitae Sanctorum Columbani (VC I, 31).

Though the $6^{\text {th }}$ and $7^{\text {th }}$ centuries are considered eras poor in sources, in respect to Brunhilda, we can rely on multiple contemporary or near-contemporary works. However, this relative abundance within scarcity is not attributed to Brunhilda personally but rather to her position of power and roles as queen and regent gained through her husband, and later, through her son and grandson. One of the most important works in regard to the assessment of Brunhilda is the work of Gregorius Turonensis entitled Decem Libri Historiarum. The author was personally aquainted with the queen, and we know from Venantius Fortunatus that Gregory was even indebted to Brunhilda for having intervened on behalf of his appointment as bishop of Tours (Venantius Fortunatus, carm., V 3, 11; 15, 15). Gregory stays silent about such personal themes, but the information cannot be ignored when analyzing the image of Brunhilda he outlined. Our other sources are made up of Venantius Fortunatus' poems. Venantius Fortunatus was an Italian-born poet, who, after having completed his classical roman education in Ravenna, went to Gaul in search of a cure for his eye disease in Tours. Here, he met Gregory, who became his friend and main protector. He arrived in Sigebert I's Austrasian court in Metz at the most opportune moment; he had a chance to let his knowledge shine on the occasion of Sigebert and Brunhilda's marriage (566). He kindly presented his hosts with several of his works, writing a panegyricus and an epithalamium for them as well. Under the financial patronage of Sigebert I, he paid visit to several Merovingian kingdoms during his travels (Reydellet, 1981: 306-308). The facts listed, as well as the poet's close relationship to Sigebert I.'s court, must also urge caution in regard to his accounts of Brunhilda's person.

$7^{\text {th }}$ century sources have a much more hostile attitude towards Brunhilda. In Visigothic King Sisebut's hagiographic work on the life and suffering of Gallic Bishop St. Desiderius (Vita Sancti Desiderii), the opponents of the Bishop of Vienne, Theuderic, ruler of Burgundia, and his grandmother, Brunhilda, have roles just as important as the Bishop himself ${ }^{2}$. This work is a unique example of contemporary political propaganda,

my article: "Brunchilde vizigót hercegnő alakja a kora középkori forrásokban". Publicationes Universitatis Miskolcinensis, Sectio Pbilosopbica, Tom. XVIII. Fasc. 1. 2014, 107-122.

${ }^{2}$ Monumenta Germaniae Historica, Scriptores Rerum Merovingicarum III, Passionesvitaeque Sanctorum Aevi Merovingici. Ed. B. Krusch. Hannover, 1896. 620-645.; Miscellanea Wisigothica. Ed. Juan Gil. Sevilla, 1972. 53-68. 
a literary manifesto of the current Visigothic-Frankish political relations which favors the Visigoths, and is therefore to be treated with reservations. Fredegarius' Chronica could be another possible reference point, though it is possible that the author had used Sisebut's work as inspiration, since the Vita Desiderii became famous in Burgundy as well soon after its writing (Martín Iglesias, 1995: 165-185; Fredegarius, 1960). Pope Saint Gregory the Great was also in contact with Brunhilda, but the author's impartiality is called into question by Ian Wood, and I myself accept this proposition as well: since the introduction of papal church reforms in Gaul depended largely on Brunhilda, inciting her anger was not advisable (Wood, 1994: 126-127). Chronologically speaking, our latest occurring source is the biography of Saint Columban (Vitae Sanctorum Columbani), which is a hagiographic creation as well (Jonas, 1905). In respect to hagiographic works, the $7^{\text {th }}$ century may be regarded as a dividing line where important new elements appear, especially considering the biographies of bishops who participated in political matters; Desiderius' biography, among others, can be classified into this category (Wallace-Hadrill, 1983: 75-93, especially 88-89).

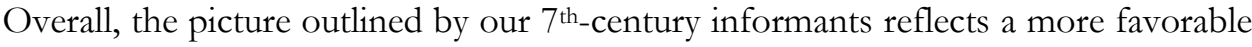
portrait of the queen than the works of subsequent authors. In my study, I will endeavor to find answers that might reveal what led to such a great change in the perception of the queen; had her own actions given rise to changes in the judgment of authors, or had other motives also played a role in the painting of a darker picture?

\section{Precedents}

We cannot consider it a mere coincidence that Athanagild had both of his daughters married into the Merovingian Dynasty; Brunhilda's older sister, Galswintha, was betrothed to Chilperic, king of Neustria. The practice of marriage between Frankish and Visigothic kings and princesses showed an extraordinary intensity in the $5^{\text {th }}$ to $7^{\text {th }}$ centuries. Clovis' daughter, Chlotchild, (Gregorius Turonensis, 1951: III 1, 10) married Visigothic ruler Amalaric, while Riguntha (Gregorius Turonensis, 1951: V 38; VI 18, 34, 45.; VII 9, 10, 39), daughter of Chilperic, was betrothed to Reccared, but the marriage did not happen due to Chilperic's murder; Riguntha later lived a dissolute life (Gregorius Turonensis, 1951: XI 34). Leovigild's eldest son, Hermenegild, had also received a Frankish bride, Ingunda - daughter of Sigebert and Brunhilda (Gregorius Turonensis, 1951: IV 38; Iohannes Biclarensis, Chronica, 579, 2). Following Hermenegild's rebellion against his father, Ingunda and her son were captured by the Byzantines on the Iberian Peninsula, and she died in Africa during the journey to Constantinople (Gregorius Turonensis, 1951: V 38; VI 40, 43.; VIII 18, 21, 28). Brunhilda did everything within her power to free her daughter and grandson from Byzantine captivity, but all of her efforts were in vain (Epistolae Austrasicae, 27, 28, 43, 44, 45). The engagement of Ermenberga, daughter of Visigothic King Witteric, to Theuderic, King of Burgundy, also ended miserably. According to Fredegarius, 
Theuderic had sent the girl back to her father without her dowry only a year after her arrival to Châlon (Fredegarius, IV 30) ${ }^{3}$. The father, incited to a terrible wrath by the blow, began searching for allies to avenge this grievance, eventually finding these in Chlothar (Neustria), Theudebert (Austrasia) and Lombard King Agilulf (Fredegarius, IV 31).

The specific purpose of the above-mentioned marriages is not overly difficult to see; they can be interpreted as conscious political strategies for building alliances, since the relationship between the Visigoths and the Franks had significantly deteriorated due to the $5^{\text {th }}$-century Frankish expansion in Gaul, the Frankish-Burgundian alliance and Clovis' diligent efforts to oust the Visigoths from Gaul. From the second half of the 490s, tension grew between the two sides; therefore, in 502 Gothic King Alaric II (Gregorius Turonensis, 1951: II 35) ${ }^{4}$ met Clovis on an island in the Loire, the border river between the two kingdoms, to put an end to the hostilities and to sign a treaty of friendship (amicitia) (Gregorius Turonensis, 1951: II, 35; Wolfram, 1988: 192) ${ }^{5}$. The peace, however, did not prove to be a lasting one as in 507 Theuderic the Great had to caution both sides to change their behavior. Alaric had to be warned to refrain from provoking the Franks, while Clovis had to be reminded to uphold the treaty of friendship. Finally, the situation had escalated to armed conflict in the same year at an extremely unfavorable time for Alaric because his father-in-law, Theuderic the Great, could not provide the Visigoths with any military support on the day of the Battle of Vouille since his troops were tied down in Italy at the time. This fact decided the fate of the losing Visigoths and that of the king himself: Alaric II most likely suffered a mortal blow at the hands of Clovis. The Visigoths were forced out of Gaul; they could only retain Septimania, a small section of their Gallic, Toulouse-centered kingdom, and even that only with the military assistance of Ostrogoth ruler Theuderic the Great (Isidorus, HG, 36; Gregorius Turonensis, 1951: II 37) ${ }^{6}$. Gregory of Tours clearly attributed the Frankish-Visigothic opposition to Clovis' commitment to Orthodoxy, which is true in part (Gregorius Turonensis, 1951: II 37). Clovis' conversion to Orthodoxy ${ }^{7}$ had provided him with an excellent pretense to step into the role of protector of the

\footnotetext{
3 "Post anni circulum Ermenbergam expoliatam a thiasuris Spaniam retransmisit".

${ }^{4}$ Visigothic King Alaric II (484-507) had married Theodegotha, daughter of Theuderic the Great, and thus he could claim a political alliance with the most powerful barbarian ruler. Theuderic the Great met his obligations as an ally and provided support to the Visigoths, but only after the Battle of Vouillé and so it was that the Visigoths were forced out of their territory. ${ }^{5}$ Gregory remembers the friendly meeting between Alaric and Clovis initiated by the Visigoth in the following way: "Coniunctique in insula Ligeris, quae erat iuxta vicum Ambaciensim terreturium Urbis Toronicae, simul locuti, comedentespariteracbibentes, promissasibiamicitia, pacifici discesserunt".

${ }^{6}$ The Frankish-Visigothic conflict played an important role in the shaping of Hermenegild's political alliances during his rebellion against his father as well. On the issue, see: Horváth, 2011: 14-26.

${ }^{7}$ On the conversion of Clovis, see: Wood, 1994: 44-48.
} 
Orthodox religion -as well as the faith of the Romans!- against the Arian or heretic Goths. This conversion helped the Frankish ruler into an entirely different political situation: it elevated him from among the barbarian rulers and raised him up next to the Romans, facilitating his adoption as their ally ${ }^{8}$.

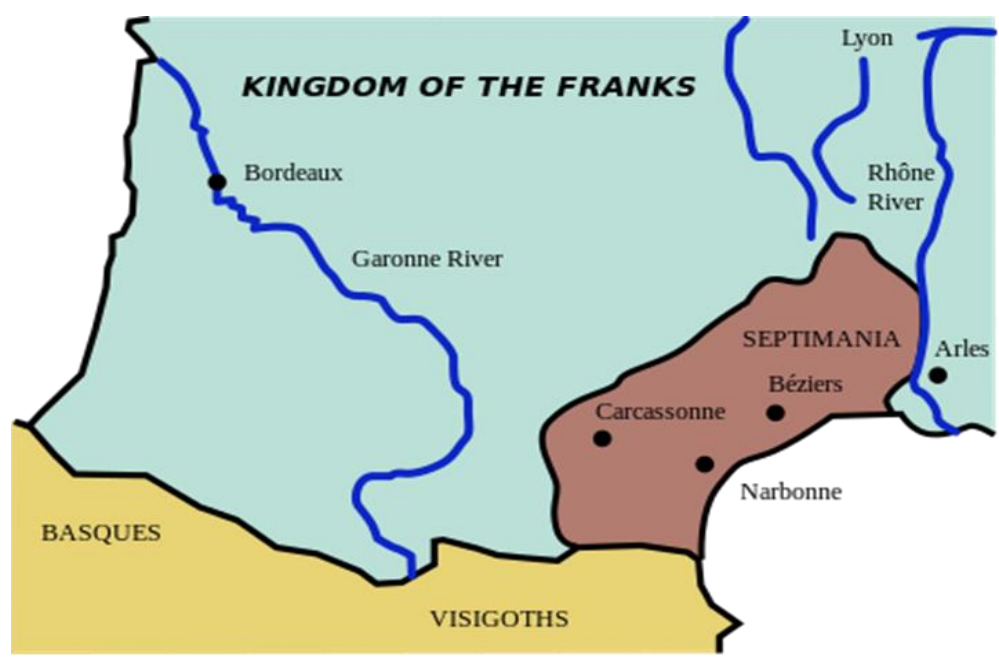

Figure 1. The location of Septimania, the remaining Visigothic territory

In connection with the upcoming marriage of Sigebert and Brunhilda, Gregory of Tours called for special attention to a $6^{\text {th }}$-century Frankish practice. In his opinion, Sigebert wanted to break away from his brothers' habit of marrying women of unworthy social positions, sometimes even slaves (Gregorius Turonensis, 1951: IV 38). The women mentioned by Gregory lived together with their lords as concubines (concubina), which was common among the barbarian courts, and although this mode of coexistence was completely at odds with Christian beliefs, the Church apparently was not strong enough to put an end to the prevailing practice. Male offspring born of such relationships were not considered fit to rule due to their illegitimate origins. In many cases, the high priests who had the ruler's favor turned a blind eye to this violation of Christian morality. In addition to the institution of concubinage, another recurring problem in the $6^{\text {th }}$ and $7^{\text {th }}$ century marriages of Merovingian kings was the practice of polygamy. This may be well observed in Chlothar's case, who married Ingunda first and when she sought his help in finding a husband for her sister, she received the following reply: "[...] I sought for a man of riches and wisdom to unite to your sister but I found no one better than myself. And so allow me to tell you that I have married her, which I think will not displease you".

\footnotetext{
${ }^{8}$ On the issue of Arianism, see: Sáry 2012a and Sáry 2012b.
} 
Following Chlothar's death in 561, conflict broke out among his four sons Charibert I, Gunthram I, Sigebert I and Chilperic I. They had all inherited the rex title after their father's death, but they shared the areas of the kingdom, so they came into conflict with each other almost immediately after the division, as did later their children, who inherited the political oppositions. In the case of Chlothar's children, we speak in part of step-siblings as he had Charibert, Gunthram and Sigebert by Ingunda, and Chilperic by Aregunda (Gregorius Turonensis, 1951: IV 3). Although they did not question Chilperic's right of succession, the siblings who shared a mother had a more cohesive relationship with one another than with their step-brother - as long as it served their interests.

Out of all the barbarian kingdoms, only the Visigothic state prohibited polygamy, namely with the Lex Visigothorum. The Lex Romana Visigothorum issued for Roman subjects also ruled that married men may not take concubines, but this law regulated Roman practices in writing, not Germanic ones (Fonay Wemple, 1981: 39) ${ }^{9}$. The attitudinal variations manifested in the issue of polygamy also highlight the significant differences in the Romanization of the Franks and the Visigoths at the time. This difference in mentality might have led, in part, to the tragic fate of Brunhilda's sister, Galswintha. According to Gregory of Tours, "although he had already too many wives, [Chilperic] asked for her sister Galsuenda, promising through his ambassadors that he would abandon the others [...]". After the wedding, the king did not comply with his promise, as his wife had to suffer constant humiliations due to his ongoing affair with one of his earlier concubines, Fredegunda. Galswintha confronted her husband and asked to be allowed to return to Hispania, leaving the treasures she had brought with her to Chilperic. The king did not want to give his consent for his wife to leave him, so as a kind of a solution to the conflict, he had her assassinated instead (Gregorius Turonensis, 1951: IV 28). However, the death of Galswintha planted the seed of further feuds in respect to the decades-long enmity between Brunhilda and Fredegunda on one hand, and Chilperic and his brothers on the other. Wallace-Hadrill believes this murder to be the main driving force behind future events as well (Wallace-Hadrill, 1982: 134-135, 205). We have no knowledge of an immediate blood feud after the murder (Gregorius Turonensis, 1951: IV 28). Brunhilda did not receive her deceased sister's estates; she only received the city of Cahors in 587 through the Treaty of Adelot, while the remaining parts of Galswintha's dowry or "morganegyba" (morning gift) (Gregorius Turonensis, 1951: IX 20) ${ }^{10}$ were acquired by Gunthram and remained in his possession until his death (Gregorius Turonensis, 1951: IX 20). Undoubtedly, this incident presented an excellent opportunity for Chilperic's brothers, and certainly this was also what launched the rivalry between Fredegunda and Brunhilda, which was compounded in time by newer conflicts.

\footnotetext{
${ }^{9}$ Leges Visigothorum III 4, 9.; 6, 2.; Lex Romana Visigothorum, II, 21, 1.

${ }^{10}$ On the issue of dowry and wedding gifts see: Koncz, 2012: 68-69.
} 


\section{The Marriage}

For the sake of easier interpretation and following of events, I have tried to divide Brunhilda's life into units, four major stages can be distinguished in her life. The first period (566-575), she spent on the side of Sigebert as queen of Austrasia and had already become relatively influential. There are hardly any records from this era, but it is certain that she was able to maintain her spousal role next to her husband because she fulfilled the task required by her gender: she gave birth to a son who lived. This son later assumes the throne as Childebert II. She had a total of three children with Sigebert; aside from Childebert, two daughters, Ingunda, whose marriage I have already mentioned, and Chlodosinda. Based on Gregory of Tours, it may be deduced that a close relationship might have developed between Brunhilda and her husband. She might have had influence over her husband, as the words of a palace noble suggest: Ursio had once said to Brunhilda after her husband's death: "[...] let it suffice for you to have ruled under your husband [...]". The comment must be seen as a strong exaggeration as Sigebert's actions clearly indicate that he was a proactive ruler with independent policies, not a puppet sitting on a throne. In my view, however, it is likely that he listened to his wife's opinion on certain issues, especially regarding church appointments (we know that Brunhilda had interceded on behalf of many). She most certainly gained greater leeway in ecclesiastical matters and not in the stricter political life, although obviously the two could not strictly be separated from one another. It can be established that during the nine years of her first marriage (566-575), she did not have to face any major problems, because otherwise our main source, Gregory of Tours, would have undoubtedly reported it.

The second half of the $6^{\text {th }}$ century was an extremely eventful period in the history of the Merovingian kingdoms, full of bloody wars, ruthless reckonings and fratricides. After the death of Chlothar, the Avars invaded Gaul and Sigebert's army marched against them; taking advantage of this situation, his brother, Chilperic, devastated his lands and occupied several cities under Sigebert's rule. Later, Sigebert successfully took back the cities and kept his brother's son as hostage, whom he placed under guard in Ponthion for a year, then returned him to his father after having secured his oath of allegiance. The next sharp conflict was caused by Chilperic's marriage, which I have already mentioned above and which had a long-term impact on the history of the Merovingian Dynasty. The significant turning point in Brunhilda's life can be associated with Sigebert's death in 575. 


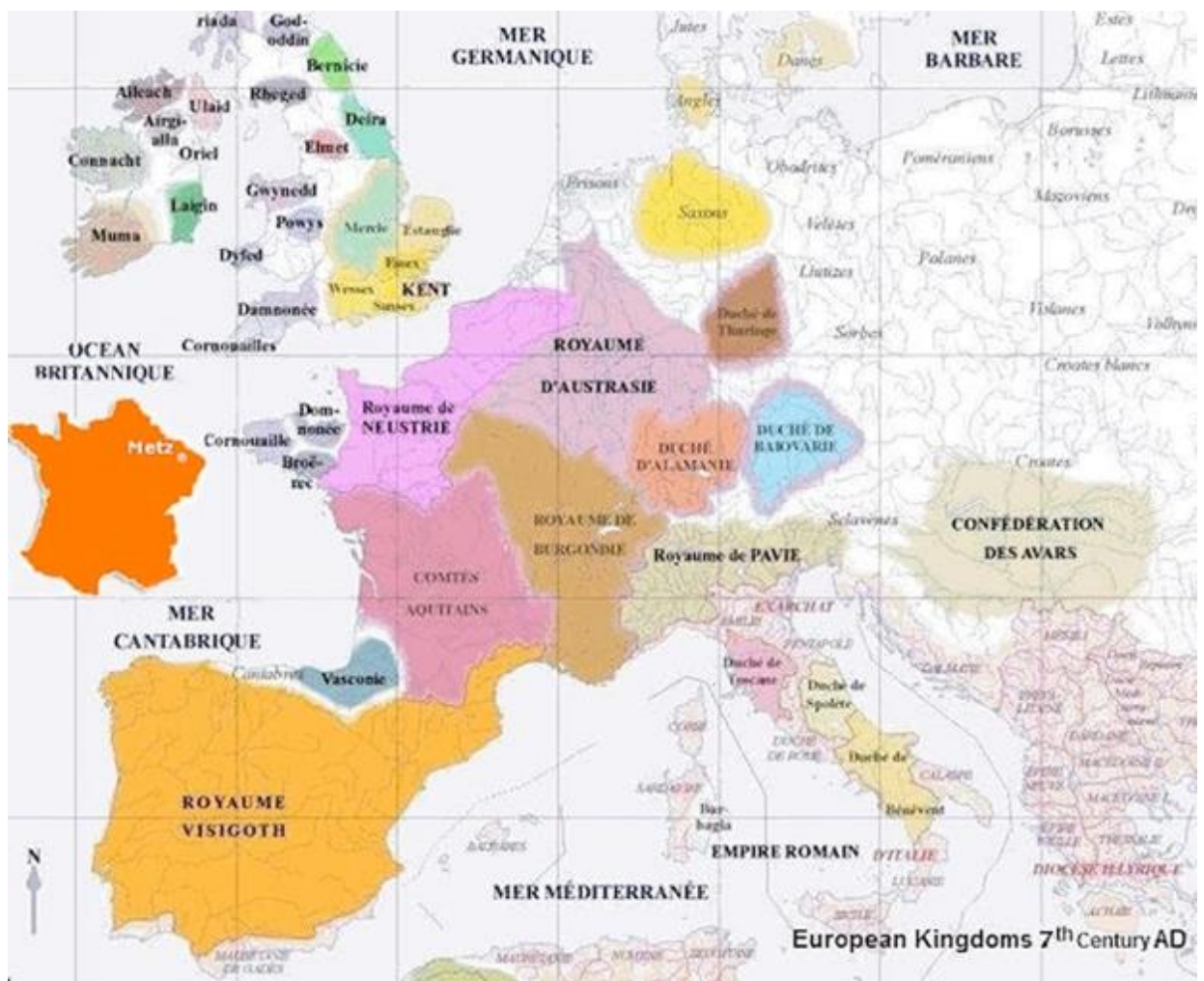

Figure 2. The extent of the Merovingian kingdoms in the $6^{\text {th }}$ and $7^{\text {th }}$ centuries

\section{Widowhood and New Marriage}

The next stage of her life covers the period between 575-585. This decade was a period laden with difficulties and struggles in the life of the queen. Sigebert became a victim of the power struggle with his brothers; after his death he was succeeded by Chilperic. According to Gregory of Tours, he was robbed of his life by two servants with knives soaked in poison, a crime that had been planned by Chilperic's wife, Queen Fredegunda (Gregorius Turonensis, 1951: IV 51). The other three brothers wanted to take revenge on Chilperic for the death of Galswintha.

To our knowledge, King Sigebert died in Vitry-en-Artois while Brunhilda was in Paris with her children at the time (Gregorius Turonensis, 1951: IV 51). The loss of her husband caused an extremely difficult period in both the queen's and her son's lives, as Childebert was still a minor then, only four years old, and the adult siblings of the deceased ruler wanted to acquire his territories after having had the young heir assassinated. In the tense situation, Gundovald $d u x$, Sigebert's reliable man, rushed to help the child and secretly took Childebert away. Gundovald made Sigebert's men 
swear allegiance to Childebert and he was made king when "[...] not yet five years old [...]" (Gregorius Turonensis, 1951: V 1). Meanwhile, Brunhilda had to fight for her own life as her opponents did not wish to see her in the role of regent, so she established privity with Merovech, son of Sigebert's half-brother, Chilperic. Merovech's life was threatened as well since his step-mother, Fredegunda, only wanted her own sons on the throne after Chilperic's death and tried to physically eliminate the sons born of other mothers, in other words, Merovech as well; so Merovech wanted to seize power during his father's lifetime (Gregorius Turonensis, 1951: IV 28) ${ }^{11}$.

After the death of Sigebert, Chilperic captured Brunhilda and exiled her to Rouen (her daughters were detained in Meaux). Here, Merovech secretly contacted her and, to cement their alliance, married the older woman. The marriage was against canon law and seizing the opportunity, Chilperic wanted to separate the spouses, who had found refuge in St. Martin's Basilica in Rouen. Finally, after much persuasion, Chilperich convinced them to leave the church and his son to accompany him to Soissons, where he was kept under house arrest and later received tonsure and was sent to a convent. Merovech had not intended a monastic life for himself; therefore, he fled to the Basilica of St. Martin in Tours and planned on going to Brunhilda from there (Gregorius Turonensis, 1951: V 3; V 14). Brunhilda was in Austrasia at the time.

Surely, it must have become clear to Brunhilda even before the marriage ceremony that with Merovech she was binding her life to a weak, powerless man, so what could have motivated her to this covenant? These are two people with very different characters: Brunhilda was the embodiment of will, authority and power, while Merovech, in contrast, never got beyond intending to do something. Thinking about the events, she would have seen Merovech's biggest virtue in the fact that he was a male born of the Merovingian Dynasty who could provide a protective shield for Brunhilda, which she was in need of against the Austrasian high lords who had all but dismissed her in the wake of her husband's death. In fact, Merovech could have secured her position as queen and could have stood up against the nobility. The protective shield, however, did not prove strong enough, as the aristocrats who, following Sigebert's death, had allied themselves with Chilperic, his former political opponent, in no way wanted to enter into conflict with the strong-handed ruler in favor of Merovech, and so most of them distanced themselves from his rebel son. They were glad about just being able to convince Chilperic of their loyalty and did not want to risk their recently acquired positions for a seemingly hopeless cause. This position of powerlessness had occasionally pushed Brunhilda into humiliating situations: Chilperic had deprived her of her wealth (Gregorius Turonensis, 1951: V 48) ${ }^{12}$, though not all

\footnotetext{
${ }^{11}$ Merovech was the son of his former wife, Audovera, with whom Chilperic had had two other sons: Theidebert and Chlodovech.

${ }^{12}$ Brunhilda had entrusted the Bishop of Rouen with five sacks loaded with jewels and money, which the bishop did not return at the queen's request; she only managed to regain some of her assets with great difficulty.
} 
members of the court had abandoned her; in any event, the loyalty of her son's tutor, Gogo, who had accompanied the queen from Hispania and remained by her side through it all, must be pointed out (Gregorius Turonensis, 1951: V 46; VI 1). The marriage forged of necessity ended with the death of Merovech, whom Fredegunda probably had assassinated. It seems that this woman played a role in the loss of both of Brunhilda's husbands. A significant result of this period was that they managed to secure the throne of Austrasia for Brunhilda's son with the support of his uncle, Guthram, which was a huge success for Brunhilda as she could remain close to power beside her son.

The third stage of the queen's life is characterized by Childebert's period of reign from 585 to 596. Childebert came of age in 585 and since Chilperic had died the year before, he could independently assume his throne in relative peace. For his mother, this was the beginning of an evolution; from then on, Brunhilda would step into an increasingly real position of power. This decade, according to the sources, paints a different picture of her, that of a grandmother concerned for her grandson and flashes the portrait of a pious, church-founding queen as well. The major part of her correspondences was directed toward Constantinople in order to obtain release for her grandson who was being held hostage there. She appears before us as a queen who only wishes peace and tranquility.

\section{The Position of Power and the Period of Regencies}

The final stage of Brunhilda's life arrived with the death of her son, Childebert, and lasted until her own death, that is, the years between 596 and 613. This period was the peak of her activity, the time of her fulfillment; posterity has judged her mostly based on her actions committed in this period, obscuring the image found in previous sources. At first, she remained beside her grandson Theudebert II in Austrasia, governing as regent in his stead, but her enemies forced her to leave the kingdom, so in 599 she fled to her other grandson, Theuderic II, in Burgundy, where she lived for the remainder of her life. She strengthened her own role beside her grandson by relying on the aristocracy of Roman descent - she seized power with the help of mayors of the palace, Protadious and Claudius, after the murder of the former. Brunhilda's interest toward the filling of episcopal seats is noticeable throughout her entire political career, but now it becomes even more conspicuous, especially in the case of the dioceses of Cahors and Rodez, where Visigothic influence was powerful. Brunhilda's interest cannot be called altruistic though, as the territory belonged to her sister, then to her sister's husband and, finally, to her upon his death. The increase of her activity regarding episcopal seats became more striking after her escape to Burgundy. In 603, she is behind Aridius' (Lyon) and Domnolus' (Vienne) appointments as bishops and, two years after that, behind Desiderius' (Auxerre) as well. If the above facts are connected to Pope Gregory the Great's remark that in the Frankish kingdom (!) in 595 nobody took an episcopal seat 
without having paid for it first, then it becomes evident that the previous cases were also examples of simony (Nelson, 1986: 25). Later on, the Pope repeatedly reproached the queen for selling the episcopal office, among others, in 597 when he criticized Brunhilda for supporting laymen in winning episcopal seats (Wallace-Hadrill, 1983: 115-117). This practice could provide fairly large amounts of revenue, but it does not tell us anything new as it was a common phenomenon in other kingdoms of the era as well. In my view, the queen was not motivated by financial gain; the more important element in connection with this issue was the establishment of connections. Brunhilda had obviously wanted to establish, both in Austrasia and Burgundy, an ecclesiastical-political elite loyal to her, who would be grateful for the allocated offices and indebted to the queen; whom she could rely on and trust, and who could, in part, counteract the political power of the hostile lords. Since city governing in the $5^{\text {th }}$ to $7^{\text {th }}$ centuries was in the hands of bishops, the loyalty of important settlements (Vienne, Tours, Reims, Auxerre, etc.) could be secured for Brunhilda. Winning over the bishops also meant that they would strive to enforce the administrative and legal functions they were entrusted with in favor of the ruler. By the $7^{\text {th }}$ century they managed to gain particularly significant independence for themselves in Neustria and Burgundy (Moreira, 2000: 77-80)13. According to Janet Wilson, the power of Merovingian kings was insured by their reliance on cities, and they could in no way deny support to the bishops (Nelson, 1986: 23-24). The bishops supported by Brunhilda include Praetextatus, the Bishop of Rouen, for example, whom she trusted to such an extent that she sent to him her moveable assets which she managed to save from Chilperic; he was also the one to help her obtain a marriage with Merovech (Gregorius Turonensis, 1951: V 18) ${ }^{14}$. In the case of a different bishop of Rodez, Brunhilda, vigorously enforcing her will, had also managed to put her own candidate, Count Innocencius of Javols, on the Episcopal seat. He almost immediately began to harass Ursicinus, Bishop of Cahors, about gaining parishes that belonged to Rodez (Gregorius Turonensis, 1951: VI 38; Nelson, 1986: 24) ${ }^{15}$. The attention Innocencius awarded to Cahors may in no way be considered accidental: it is quite clear that in the background of the inquiry we can find none other than the queen, who wished to finally obtain her deceased sister's estates as soon as possible. The returning botheration of the Bishop of Cahors could have been a live message to the ruler about the desire to own the city.

I believe that another important motif of the Episcopal appointments is the fact that, though the queen formally acquired the political support of the high priests for her

\footnotetext{
${ }^{13}$ Friedrich Prinz has emphasized the difference between the power conferred on bishops in the late Roman period and the Merovingian era. In Merovingian Gaul they were much more forced to cooperate with other bishops, religious and secular parties, even if their positions seemed secure.

${ }^{14}$ We are talking about the period around 577, as our source refers to the Paris Synod which convened in the same year.

${ }^{15}$ Regarding this appointment Nelson points out Brunhilda's personal interests, namely that she wanted to secure the city of Cahors, her deceased sister's dowry, for herself. I myself accept this supposition as well.
} 
grandson, the way to them lead through her, making her unavoidable in the power games, and thus indispensable to Theuderic and even gaining the upper hand over him. Based on the above, it seems to me that the importance of having control over Episcopal seats lay in the technical aspects of authority, namely the seizure and preservation of power, meaning that giving away church offices was a deliberate strategic tool. On this basis, it may seem that the relationship between the bishops of Burgundy and the royal house was seamless, and so it was in most cases. Difficulties came to Brunhilda through Desiderius, Bishop of Vienne. What was the root cause of the conflict between the parties? That practice of Germanic rulers which had remained in place even after the conversion to Christianity and which, in the eyes of the church, was the most hideous manifestation of carnality: the institution of concubinage (mistresses). This custom was unacceptable to Desiderius; he put his best efforts into convincing Theuderic to marry, but he stubbornly resisted. Therefore, Desiderius regularly complained about the king going astray and had also scolded Brunhilda for accepting the situation; he had even preached about them both in church ${ }^{16}$. Despite Theuderic's stubbornness, the intention to have him married was not completely without consequences; there had been an attempt with Ermenberga of the Visigoths (Fredegarius IV 30). According to Fredegarius, however, this attempt was a failure due in no small part to the intervention of Brunhilda, who had thwarted the marriage covenant (Fredegarius IV 32). The situation had finally degenerated to the point that Desiderius refused to accept Theuderic's sons as heirs because of their illegitimacy. The bishop's impenitence and the threat to succession had finally forced the accused into action. As a remedy to the situation, in 603 the bishop was summoned to the Synod in Chalon-sur-Saône where Brunhilda and her grandson were present as well. The Synod had deposed Desiderius -Domnulus had become the bishop of the city in his steadand he was exiled to the isle of Livisium. God's servant had soon become famous; several miracles (for example, the cure of three people suffering from leprosy) were attributed to him. This popularity frightened the ruling pair; they eventually called him back to Vienne and returned him to his former office (VD 4-8).

The question may arise: why did Brunhilda (and her grandson, of course) show such stubborn resistance toward the bishop's request and the specifications of Christian morality? Theuderic probably stood baffled before the effort to rescue his morality since the everyday practice of the Merovingian court was self-evident to him, the practice to which the previously "selected" bishops had willingly turned a blind eye. Aside from his grandmother, no one dared set rules for the king; therefore, he did not take Desiderius' comments seriously for a long time. However, criticism came from other places as well, and not from just anyone, but from the exceptionally respected and popular Irish monk Columban doing missionary work in Gaul. He and his

${ }^{16}$ This conflict is shown remarkably in King Sisebut's work, Vita Desiderii written around 613, which is excellently analyzed by Fontaine, 1980: 93-129. (The Vita Desiderii hereinafter refered to as: VD) 
companions had come to Austrasia from Bangor; he maintained a good relationship with the court and was personally acquainted with Brunhilda. Later on, he gained entrance into Theuderic's court as well. He founded a number of monasteries, mainly in south Austrasia and Burgundy, during his missionary work which followed the rule of Columban; more precisely, a so-called regula mixta had become prevalent in those regions, rules which were based on both the regulations of Columban and Saint Benedict and contained some unique elements as well (Fox, 2012: 176-194, 178).

Once, when the royal grandmother asked the monk to bless her grandchildren born from a concubine, Columban refused, stating that those children would never sit on the throne as they were bastards and not born from a legal marriage (Vita Columbani I 19). This remark angered Brunhilda to such extent that, after the monk's departure, she went into a long, inconsolable rage, terrorizing the whole court with her fury. Yaniv Fox has done an excellent job in noting the counterpoint to the mentioned scene in Jonas' work. On one occasion, Columban paid a visit to the home of a Frankish noble, Autharius and his wife, Aiga; the parents introduced their children to him and he blessed them - as they had come from a Christian marriage - and predicted a wonderful future for them. According to the Vita's statement, children raised in the faith and according to Christian morality would have success in life, while bastards would fail and were doomed to die (Vita Columbani I 26.; Fox, 2012: 181-182)17.

Jonas of Bobbio points out one important aspect regarding Theuderic's prospect of marriage and we have to agree with him: the reason for which Brunhilda, or as he calls her, the second Jezebel, (Vita Columbani I 18) did not consider it important to put an end to the sinful relationship was her being afraid that should the king marry, her power over him would weaken. She must have thought that she could have more control over a concubine than she would over a wife. However, a woman of such vast experience as herself should have known that the strength of the "demons of the flesh" is more effective than the law, sometimes it is even stronger than power, not to mention that she had seemingly learned nothing from the fate of her sister. At the same time, we cannot lose sight of the fact that the position of a concubine was indeed completely different from that of a wife. However, concubines could also reach positions of power and on rare occasions, they might have even become wives -Fredegunda's case would be a good example- though the prospective spouse needed to have a suitable personality in order to grasp the opportunity. Theuderic's concubine was not such a person and Brunhilda had to have been aware of that. She must have lacked all ambition for power; she is not mentioned in the sources at all and we have practically no information about her, which would not be the case if she had competed against

\footnotetext{
17 The mentioned couple's children became successful members of the aristocracy, having held high offices in King Dagobert I.'s court; furthermore, they founded a number of monasteries in the regions of Meaux and Soissons and were the main supporters of Columban's monastic movement. In contrast, Theuderic's children have received a cruel punishment as they all died young.
} 
Brunhilda for the title of queen. That is why she could remain the king's concubine; that is why the queen did not want to banish her; she was not considered an enemy and could be kept under control. Nevertheless, she also knew that her young grandson needed someone by his side, but she wanted to provide Theuderic with a woman in accordance with her own interests. This was the way in which the ensuing situation provided reassurance.

In my view, Brunhilda had become tired; she was already old at the time of the events, with many an intrigue and struggle behind her. She only wanted one thing, but that she wanted fiercely: for everything to stay the same, especially her influence. She did not want a situation she clearly dominated to be replaced with an uncertain one, to fight an unknown, young, energetic woman for influence over Theuderic. That is the reason she resisted the pressure of the holy men, that is why she supported the existing situation and had no intentions of changing it. Therefore, it was not religion but political tactics that had the main role in the unfolding events which ultimately resulted in Desiderius paying with his life and Columban being forced to leave Burgundy (VD 18; Vita Columbani).

Brunhilda's last political game ended with her terrible death. Theuderic marched to Austrasia against his brother, killed him and his son, and then started after Fredegunda's son, Chlothar. His unexpected death prevented the execution of Theuderic's plans; Brunhilda was left alone. As a solution, she raised Theuderic's eldest son, Sigebert II, to the throne and was now regent beside her great-grandson. Due to the death of her grandchildren, both Burgundy and Austrasia became united under her rule, a fact that opposing Austrasian nobles, including such influential personalities as Arnulf of Metz, Pippin of Landen, or Burgundian mayor of the palace Warnachar, wanted to prevent, so they offered the regency to the King of Neustria, Chlothar II (Fredegarius IV 37-42). This gesture reunited the three territories under one rule. Brunhilda, Sigebert and his five siblings were captured; the latter were executed. Chlothar charged the queen with ten murders, including those of both of her husbands, her grandchildren and great-grandchildren and Chilperic's assassination as well. She was paraded around on a camel's back as ridicule and then suffered a horrible death: she was torn apart by horses.

In history, Brunhilda's name has become synonymous with wickedness, but should this be the way we think of her? In my opinion, Brunhilda was a much more complex personality than our authors describe. Let us not forget that our sources were driven by their commitment to Brunhilda's enemies when they drew a much darker picture of the queen. The fact that she was a woman made her especially suited to be the embodiment of sin. During the $6^{\text {th }}$ and $7^{\text {th }}$ centuries, the fact itself that she could obtain a position of power and authority for herself was considered a great achievement for a woman. Even though she gained power mostly through men, she owed the fact that she could keep it primarily to herself. The other extraordinary achievement associated with her name is the duration of her reign: from 575 to 613; 
that is, she fulfilled a role in the royal court for a total of thirty-eight years, either as an influential wife, or as regent on the side of one family member or another. This in itself is a testimony to remarkable, more than considerable capabilities. She skillfully used church offices to create political communities of interest and to strengthen her own position. In addition, there was another aspect to her: she could be a worried mother and grandmother as well; this picture unfolds mainly in connection with her relatives, who were either in the Visigothic Kingdom or taken as Byzantine captives. As contradictory as it may sound, Brunhilda had a kind face as well. She sincerely respected worthy clergymen; she founded churches and monasteries; she supported the Pope's reform efforts, and not just for the expected royal performance but out of inner conviction (Wood, 1994: 131, 134). Unquestionably, she did not shy away from any means necessary to remain in power, but in this she was not alone. She was in no way crueler or wickeder than the male rulers of her time, but society expected something different from a woman. She did not exhibit behavior demanded of her gender as neither her duties nor the environment in which she lived had made that possible; the passing years forced her to exude masculine strength; otherwise, she would have failed in her own world within seconds.

\section{Works cited}

Bardsley, Sandy (2007). Women's Roles in the Middle Ages. London: Greenwood Press.

Iohannes Biclarensis (1894). Chronica. Ed. Th. Mommsen. Berlin: (Monumenta Germaniae Historica. Auctores antiquissimi, 11).

Epistolae Austrasicae (1892). Ed. W. Gundlach. Berlin. (Monumenta Germaniae Historica. Epistolae, 3).

Fonay Wemple, Suzanne (1981). Women in Frankish Society. Marriage and the Cloister, 500 to 900. Philadelphia: University of Pennsylvania Press.

Fontaine, Jacques (1980). King Sisebut's Vita Desiderii and the Political Function of Visigothic Hagiography. In: James, Edward (ed.). Visigothic Spain: New Approaches. Oxford: Oxford University Press. 93-129.

Fox, Yaniv (2012). The bishop and the monk: Desiderius of Vienne and the Columbanian movement. Early Medieval Europe, 20/2. 176-194.

Fredegarius (1960). Chronica. Ed. Wallace-Hadrill. London: Thomas Nelson and Sons.

Gregorius Turonensis (1951). Decem Libri Historiarum. Ed. B. Krusch-W. Levison. Hannover: Hahn. (Monumenta Germaniae Historica. Scriptores Rerum Merovingicarum, $1,1)$.

Horváth, Emőke (2008). Iohannes Biclarensis krónikája. Aetas 23/1. 116-127. 
Violence and Passion at Court: Brunhilda, a Visigothic Princess

Horváth, Emőke (2011). Hermenegild bűne a megtérés? In: Horváth, Emőke (ed.). Bün, bünhödés, büntetés. Budapest: L' Harmattan.

Jonas (1905). Vitae Sanctorum Columbani. Ed. Bruno Krusch. Hannover (Monumenta Germaniae Historica. Scriptores Rerum Merovingicarum, 4).

Koncz, Ibolya Katalin (2012). A jegyajándék és a hitbér jogtörténeti gyökerei. Publicationes Universitatis Miskolcinensis. Sectio Juridica et Politica 30/2. 67-73.

Lex Romana Visigothorum (1849). Ed. G. Haenel. Leipzig: Teubner.

Martín Iglesias, José C. (1995). Un ejemplo de influencia de la Vita Desiderii de Sisebuto en la hagiografía merovingia. Minerva, 9. 165-185.

Miscellanea Wisigothica (1972). Ed. Juan GIL. Sevilla: Publicaciones de la Universidad de Sevilla.

Nelson, Janet (1986). Politics and Ritual in Early Medieval Europe. London-Ronceverte: The Hambledon Press.

Passiones vitaeque Sanctorum Aevi Merovingici (1896). Ed. Bruno Krusch. Hannover: Hahn. (Monumenta Germaniae Historica. Scriptores Rerum Merovingicarum, 3).

Reydellet, Marc (1981). La Royauté dans la littérature latine de Sidonie Apollinaire à Isidore de Seville. Rome: Ecole Francaise de Rome.

Sáry, Pál (2012a). Nagy Theodosius „Cunctos Populos” kezdetű rendeletének elemzése. Publicationes Universitatis Miskolcinensis. Sectio Juridica et Politica 30/2. 147-160.

Sáry, Pál (2012b). Iustinianus császár egyháapolitikai rendelkezései. Budapest: Szent István Társulat.

Tours-I, Gergely (2010). Korunk története. A frankok története. Ed. Adamik, Tamás. Translation. Mezei, Mónika-Adamik, Tamás. Pozsony: Kalligram.

Venantius Fortunatus (1881). Opera Poetica. Ed. F. Leo. Berlin. (Monumenta Germaniae Historica. Auctores antiquissimi, 4, 1), carm., V, 3, 11; 15, 15.

Wallace-Hadrill, John Michael (1982). The Long-Haired Kings. Toronto-Buffalo-London: University of Toronto Press.

Wallace-Hadrill, John Michael (1983). The Merovingian Saints. In: The Frankish Church. London: Clarendon Press. 75-93.

Wallace-Hadrill, John Michael (1983). The Merovingians and the Papacy. In: The Frankish Church. London: Clarendon Press. 110-122.

Wolfram, Herwig (1988). History of the Goths. Berkeley-Los Angeles-London: University of California Press.

Wood, Ian (1994). The Merovingian Kingdoms 450-751. London-New York: Longman. 